\title{
Pathogen Reduction Technology Treatment of Platelets, Plasma and Whole Blood Using Riboflavin and UV Light
}

\author{
Susanne Marschner Raymond Goodrich \\ CaridianBCT Biotechnologies, Lakewood, CO, USA
}

\section{Keywords}

Pathogen reduction - Riboflavin - Transfusion safety

\section{Summary}

Bacterial contamination and emerging infections combined with increased international travel pose a great risk to the safety of the blood supply. Tests to detect the presence of infection in a donor have a 'window period' during which infections cannot be detected but the donor may be infectious. Agents and their transmission routes need to be recognized before specific tests can be developed. Pathogen reduction of blood components represents a means to address these concerns and is a proactive approach for the prevention of transfusion-transmitted diseases. The expectation of a pathogen reduction system is that it achieves high enough levels of pathogen reduction to reduce or prevent the likelihood of disease transmission while preserving adequate cell and protein quality. In addition the system needs to be non-toxic, non-mutagenic and should be simple to use. The Mirasol ${ }^{\circledR}$ Pathogen Reduction Technology (PRT) System for Platelets and Plasma uses riboflavin (vitamin B2) plus UV light to induce damage in nucleic acid-containing agents. The system has been shown to be effective against clinically relevant pathogens and inactivates leukocytes without significantly compromising the efficacy of the product or resulting in product loss. Riboflavin is a naturally occurring vitamin with a well-known and well-characterized safety profile. The same methodology is currently under development for the treatment of whole blood, making pathogen reduction of all blood products using one system achievable. This review gives an overview of the Mirasol PRT System, summarizing the mechanism of action, toxicology profile, pathogen reduction performance and clinical efficacy of the process.

\author{
Schlüsselwörter \\ Pathogenreduzierung · Riboflavin · Transfusionssicherheit
}

\section{Zusammenfassung}

Bakterielle Kontaminierung und daraus resultierende Infektionen in Kombination mit dem erhöhten internationalen Verkehr bilden ein großes Risiko für die Sicherheit der Blutversorgung. Tests, um das Vorhandensein einer Infektion bei einem Spender nachzuweisen, haben ein Zeitfenster, währenddessen Infektionen nicht detektiert werden können, der Spender aber dennoch infektiös ist. Krankheitserreger und ihre Übertragungsrouten müssen bekannt sein, bevor spezifische Tests entwickelt werden können. Die Pathogenreduzierung von Blutkomponenten ist einer der Hauptansatzpunkte, um diesen Bedenken Rechnung zu tragen, und stellt einen proaktiver Ansatz zur Vermeidung von Krankheiten, die durch Transfusion übertragen werden, dar. Von einem Pathogenreduzierungssystem wird erwartet, dass einen ausreichend hohen Grad der Pathogenreduzierung ermöglicht, um die Wahrscheinlichkeit einer Krankheitsübertragung zu verringern, wenn nicht gar zu vermeiden, ohne die Zell- bzw. Proteinqualität in nennenswertem Umfang zu verschlechtern. Darüber hinaus muss das System nichttoxisch und nichtmutagen sein und solle einfach anzuwenden sein. Das Mirasol ${ }^{\circledR}$ Pathogen Reduction Technology (PRT) System für Thrombozyten und Plasma nutzt Riboflavin (Vitamin B2) plus UV-Licht, um eine Schädigung von Nukleinsäure enthaltenden Krankheitserregern zu bewirken. Die Wirksamkeit des Systems gegen klinisch relevante Pathogene wurde nachgewiesen und auch Leukozyten werden inaktiviert, ohne die Effektivität des Endprodukts signifikant zu beeinträchtigen oder mit einem Produktverlust einherzugehen. Riboflavin ist ein natürlich vorkommendes Vitamin mit einem wohlbekanntem und gut charakterisiertem Sicherheitsprofil. Dieselbe Methodik ist derzeit für die Behandlung von Vollblut in der Entwicklung, wodurch eine Pathogenreduzierung von allen Blutprodukten mit Hilfe eines einzigen Systems zu erreichen wäre. Diese Arbeit gibt eine Übersicht zum Mirasol PRT System und beschreibt zusamenfassend den Wirkmechanismus, das toxikologische Profil, die Pathogenreduzierungsleistung und die klinische Effektivität des Verfahrens.

\begin{tabular}{|c|c|}
\hline KARGER & (C) 2011 S. Karger GmbH, Freiburg \\
\hline $\begin{array}{l}\text { Fax +49 } 7614520714 \\
\text { Information@Karger.de }\end{array}$ & $\begin{array}{l}\text { Accessible online at: } \\
\text { www.karger.com/tmh }\end{array}$ \\
\hline
\end{tabular}




\section{Introduction}

Blood has a vital role in the human body, and blood transfusion can be life-saving in patients with either massive blood loss or in those unable to produce blood due to defective hematopoiesis. In most developed countries blood is fractionated into components like fresh frozen plasma (FFP), platelets and red cells concentrate for replacement or prophylactic therapies. A number of measures have been introduced in the past decade to prevent transmission of infectious agents during transfusion of blood components. Donor screening and deferral procedures in addition to serologic and nucleic acid testing helped in making blood a safer product for transfusion [1]. These efforts have drastically reduced the risk of classical transfusion-transmitted infectious agents such as HBV, HCV and HIV. However, even though screening techniques are a very reliable way to detect many lethal viruses, blood transfusion still poses risks for the following reasons: i) the window period of pathogens during which an infectious donor cannot be detected has been reduced, but not eliminated by NAT screening because NAT testing is generally carried out on pooled donor samples which can raise the chance of infection due to dilution of the signal from infected donors; ii) new emerging pathogens may enter the blood supply; iii) parasites and bacteria also represent an infective risk. Routine serological testing currently does not test for various parasitic diseases, and limited test methods exist [2]. Bacteria may be present in asymptomatic donors or, more frequently, enter the blood during collection. Efforts to reduce the risk of bacterial contamination of platelet products is of high importance since platelets are stored at room temperature, allowing for bacterial proliferation, and also because platelets are frequently given to patients with impaired immune systems who are more susceptible to bacterial infections. In developing countries the risk of all transfusion-transmitted infections is still high due to insufficient funding and organization of health services.

Methods aimed at reducing the pathogen load in labile blood products have been developed in recent years and are aimed at further reducing the risk of transmission of pathogens and adverse events. Targeting of nucleic acids has been the primary approach to inactivate pathogens and donor leukocytes in cellular blood products. This review provides an overview of the Mirasol ${ }^{\circledR}$ Pathogen Reduction Technology (PRT) System for Platelets and Plasma (CaridianBCT Biotechnologies, Lakewood, CO, USA) and describes the Mirasol System for Whole Blood currently in development. The mechanism of action, toxicology profile, pathogen reduction performance and clinical efficacy of treated products are discussed.

\section{Mirasol PRT System}

\section{Mechanisms of Action}

The ability of riboflavin (RB), vitamin B2, to act as a photosensitizer mediates selective damage to nucleic acids upon exposure to light, without binding to cells and proteins [3]. RB associates with nucleic acids and mediates an oxygen-independent electron transfer process leading to the modification of nucleic acids, primarily on guanine residues, and the conversion of RB to its photoproduct lumichrome (LC) [4-8]. Compared to the use of UV light alone, which causes reversible nucleic acid damage, damage induced by RB is irreversible since replication and repair processes are impaired due to the guanine base modification [9]. The number of lesions occur at a frequency of approximately one in every 350 base pairs (bp) [10]. Nucleic acid damage may be less frequent in mitochondrial DNA as shown by Janetzko et al. [11]. Mitochondrial DNA isolated from Mirasol-treated platelets could be amplified using $1 \mathrm{~kb}$ but not $4 \mathrm{~kb}$ primers.

Martin et al. [12] evaluated the effectiveness of RB inactivation of phage as a function of wavelength of light. At most of the wavelengths examined, the ability of RB to inactivate virus followed the absorption pattern of $\mathrm{RB}$ in aqueous media. For wavelengths of 310-320 nm, where the absorbance of $\mathrm{RB}$ in water is decreasing, the inactivation of the virus was increased, enhancing the levels of pathogen inactivation compared to the use of UV light alone. Based on this work the Mirasol system was designed to use RB at a final concentration of approximately $50 \mu \mathrm{mol} / \mathrm{l}$ and UV light from a fluorescent lamp with the energy centered at $313 \mathrm{~nm}$. The majority (99\%) of the total energy reaching the product through the plastic is in the UVB $(280-315 \mathrm{~nm})$ and UVA $(315-400 \mathrm{~nm})$ spectral regions. The peak wavelength chosen for the Mirasol process preferentially targets RB associated with nucleic acids, directing the damage specifically to nucleic acids. This light source does not emit energy in spectral regions where cytochrome $\mathrm{C}$, flavin mononucleotides (FMN) and flavin adenine dinucleotides (FAD) absorb - co-factors that are essential for mitochondrial function and activity.

\section{Toxicology and Safety}

$\mathrm{RB}$ is a water soluble, rapidly excreted vitamin that cannot be stored by the body. It is the precursor for FMN and FAD, major co-enzymes that participate in one-electron transfer processes in the human body. It is classified by the Food and Drug Administration as a Generally Recognized as Safe (GRAS) product (21 CFR 184, 1695, 2001). The safety of RB has been demonstrated for oral, subcutaneous, intraperitoneal and intravenous routes of administration [13-16]. Neonates undergoing phototherapy for neonatal jaundice are often temporarily RB-deficient due to the overlapping light absorption spectra of RB and bilirubin [17-20]. Although concerns were expressed about the long-term effects of $\mathrm{RB}$ plus direct phototherapy in neonates [8], there have been no 
Table 1. Virus log reduction results from standard in tivity (TCID50) vitro assays for infec-

\begin{tabular}{llcl}
\hline Virus & Model virus used & Log/ml reduction ${ }^{\text {a }}$ & Type \\
\hline HIV, latent & intracellular human HIV & 4.5 & enveloped \\
HIV, active & cell-associated human HIV & 5.9 & enveloped \\
West Nile virus & West Nile virus & $\geq 5.1$ & enveloped \\
Hepatitis C virus & sindbis virus & 3.2 & enveloped \\
Hepatitis B virus & pseudorabies virus & 2.5 & enveloped \\
Rabies virus & vesicular stomatitis virus & $\geq 6.3$ & enveloped \\
Influenza virus, avian flu virus & influenza A virus & $\geq 5.0$ & enveloped \\
Cytomegalovirus & infectious bovine rhinotracheitis virus & 2.1 & enveloped \\
Human B19 virus & porcine parvovirus & $\geq 5.0$ & non-enveloped \\
Hepatitis A virus & human hepatitis A & 1.8 & non-enveloped \\
Hepatitis A virus & encephalomyocarditis virus & 3.2 & non-enveloped \\
Chikungunya virus & La Reunion clinical isolate & 2.1 & enveloped \\
\hline${ }^{a}$ Results expressed as ' $\geq$ ' indicate that the pathogen load was reduced to the limit of detection of the assay. \\
\hline
\end{tabular}

Table 2. Parasite log reduction results from standard in vitro assays for infectivity or bio-assay in hamsters [74-78]

\begin{tabular}{lll}
\hline Disease & Parasite & Log/ml reduction ${ }^{\mathrm{a}}$ \\
\hline Leishmaniasis & Leishmania donovani infantum & $\geq 4.0$ \\
Malaria & Plasmodium falciparum & $\geq 3.2$ \\
Chagas disease & Trypanosoma cruzi & $\geq 5.0$ \\
Babesiosis & Babesia microti & $\geq 4.0$ \\
Scrub typhus & Orienta tsutsugamushi & $\geq 5.0$ \\
\hline
\end{tabular}

a'Results expressed as ' $\geq$ ' indicate that the pathogen load was reduced to the limit of detection of the assay.

reports of adverse events in the clinical setting. Indeed, a large retrospective analysis of over 55,000 infants who had undergone phototherapy demonstrated no excess incidence of childhood leukemias over an average of 9 years of followup [21].

In the Mirasol process $35 \mathrm{ml}$ of RB $(500 \mu \mathrm{mol} / \mathrm{l}$ in $0.9 \%$ saline) is added to products before exposure to UV light. Photolysis of $\mathrm{RB}$ results in the formation of LC, 2'-ketoriboflavin, 4'-ketoriboflavin and formylmethylflavin. These photoproducts are normal metabolites of RB and have been detected in normal non-illuminated human blood at low concentrations [22], showing that no new chemicals are introduced into blood products by this RB-based PRT system. Normal levels of RB in human blood range from 100 to $400 \mathrm{ng} / \mathrm{ml}$ (equivalent to 0.5-2 $\mathrm{mg}$ assuming a 51 blood volume). At present, the upper limit of the 'no toxic effect level' of RB remains unknown. No toxic effects have been described in the literature, with the recommended therapeutic dose up to $30 \mathrm{mg} /$ day for an adult. There are also reports of people taking more than $200 \mathrm{mg} /$ day safely for 6 months without issues [23, 24].

Whilst RB is known to be safe, extensive toxicology testing was performed to establish the safety of Mirasol-treated blood products. Toxicity of RB and its photoproducts was assessed using both in vitro and in vivo models. No toxicologically significant findings were observed in any of the studies performed. Prolonged and repeated exposure of dogs to Mirasoltreated platelets (78 exposures over 13 weeks) and exposure of dogs to large volumes of Mirasol-treated plasma via plasma exchange did not indicate any toxicity $[25,26]$. A range of other tests assessing embryo-fetal development, geno- and cytotoxicity after exposure to Mirasol-treated platelets or high levels of LC excluded any risk and toxicity. In studies with ${ }^{14} \mathrm{C}$-labeled $\mathrm{RB}$, no binding of $\mathrm{RB}$ or its photoproducts to platelets or plasma proteins was detected. No evidence of neoantigenicity was observed in either in vitro assays or in patient samples after repeated exposure to Mirasol-treated platelets [26, 27]. In an in vivo model of neoantigenicity, baboons immunized with Mirasol-treated RBCs displayed no immune response, and the recovery of radiolabeled Mirasoltreated RBCs was similar to untreated control RBCs [28]. Additionally, Mirasol treatment did not enhance the rate of acute lung injury in rats as measured in a two-event in vivo TRALI model [29].

The likely exposure of recipients to RB in the clinical setting has been calculated as $0.077 \mathrm{mg} / \mathrm{kg}$ (or $5.4 \mathrm{mg}$ ) for each product transfused, based on the assumption of an average recipient weight of $70 \mathrm{~kg}$ and average $\mathrm{RB}$ photoconversion of $18 \%$ [22]. In patient samples from the MIRACLE clinical trial no RB was detected in any patient sample, and only traces of LC $(0.06-0.07 \mu \mathrm{mol} / \mathrm{l})$ were detected $24 \mathrm{~h}$ after transfusion in two patient samples analyzed (4\%). Comparison of a $\mathrm{RB}$ exposure level of $0.077 \mathrm{mg} / \mathrm{kg}$ to the reported $\mathrm{LD}_{50}$ for intravenous RB infusion in mice of $50-100 \mathrm{mg} / \mathrm{kg}$ [15] yields a large safety factor $(649-1,299)$. The exposure level can also be compared to the levels of $\mathrm{RB}$ provided in parenteral nutrition. Based on a study by Levy et al. [30] in which RB was provided at levels of 0.43 and $0.72 \mathrm{mg} / \mathrm{kg} /$ day and no adverse effects were observed, it is recommended that low birth weight infants receive parenteral nutrition containing $0.45 \mathrm{mg} / \mathrm{kg} /$ day $\mathrm{RB}$. The above findings provide strong support for the fact that the Mirasol process does not require subsequent removal of RB and its photoproducts from treated blood components prior to transfusion. This provides much needed safety and simplicity to the pathogen reduction process while minimizing component losses due to bag transfers and/or compound removal steps. 
Table 3. Comparison of the Mirasol and culture method to inactivate or detect bacteria ${ }^{\mathrm{a}}$.

\begin{tabular}{lllcc}
\hline Bacteria & Type & Occurrence & $\begin{array}{l}\text { Mirasol \% } \\
\text { effectiveness }\end{array}$ & $\begin{array}{l}\text { Culture method } \\
\% \text { effectiveness }\end{array}$ \\
\hline Staphylococcus epidermidis & Gram-positive & 20 & 100 & 27 \\
Escherichia coli & Gram-negative & 8 & 100 & 100 \\
Bacillus cereus & Gram-positive & 7 & 100 & 100 \\
Staphylococcus aureus & Gram-positive & 6 & 90 & 53 \\
Streptococcus agalactiae & Gram-positive & 5 & 100 & 100 \\
Streptococcus mitis & Gram-positive & 5 & 100 & 100 \\
Streptococcus pyogenes & Gram-positive & 5 & 100 & 100 \\
Enterobacter cloacae & Gram-negative & 4 & 100 & 100 \\
Propionibacterium acnes & Gram-positive & 3 & 100 & 0 \\
Serratia marcescens & Gram-negative & 3 & 100 & 100 \\
Klebsiella pneumoniae & Gram-negative & 2 & 100 & 100 \\
Acinetobacter baumannii & Gram-negative & 1 & 66 & 100 \\
Yersinia enterocolitica & Gram-negative & 1 & 100 & 100 \\
\cline { 3 - 4 } Overall \% effectiveness & & & 98 & 66 \\
\hline
\end{tabular}

${ }^{a}$ Occurrence is the number of cases of contaminated platelets with the particular bacteria as reported in hemovigilance studies[33]. Percent effectiveness is the ability to inactivate or detect the particular bacterial strain at initial contamination levels of $<100 \mathrm{CFU}$ per product. Mirasol treated products had to remain culture negative during 7 days of storage flowed by a 7-day culture monitoring period (BacT/ALERT, anaerobic and aerobic 2-bottle culture system). Overall effectiveness is the multiple of the percent effectiveness with the frequency of occurrence for this agent [34].
Pathogen Reduction and Leukocyte Inactivation Performance A pathogen reduction system is expected to achieve an optimal degree of infectivity reduction, balanced with an acceptably small amount of damage to the blood component, and to pose no risk to the recipient. A high enough level of pathogen reduction needs to be achieved to reduce or prevent the likelihood of disease transmission while preserving adequate cell and protein quality. For viruses, the expected viral levels in a donor during acute and chronic infections must be considered for understanding whether a proposed method may prevent disease transmission. For bacteria, a PRT method should be able to maintain products culture-negative during storage when challenged with clinically relevant bacterial loads; for parasites and leukocytes, inactivation of these agents from infected donors or from nonleukoreduced products should be evaluated for $100 \%$ efficacy [31]. The majority of results shown in tables 1-3 were performed in plasma or platelets stored in $100 \%$ plasma. Bridging experiments have shown that the performance of the system in the presence of plateletadditive solutions (PAS) is equivalent for viral and bacterial reduction.

The Mirasol system has been shown to substantially reduce the infectious load of enveloped and non-enveloped viruses in test systems, suggesting the potential to add a significant level of protection against tested and untested viruses and to close the window period that exists for screened viruses. HBV and CMV reduction studies were performed using model viruses as well as human or murine virus (manuscripts in preparation). The Mirasol system is the only PRT technology that has demonstrated inactivation of HAV, a virus that is highly re- sistant to chemical and heat inactivation. The Mirasol system is very effective against parasites such as T. cruzi and B. microti, the causative agents of Chagas disease and babesiosis, respectively, greatly enhancing the safety of the blood product in the absence of parasite screening. Contamination of blood products with bacteria most frequently occurs at the time of phlebotomy, or from asymptomatic donor bacteremia, resulting in low levels of contamination [32]. 22 clinically relevant bacteria strains were evaluated that are responsible for $98 \%$ of severe bacterial infections after transfusion, as reported in hemovigilance reports [33]. Mirasol treatment showed overall $98 \%$ effectiveness against these strains using clinically relevant contamination levels [34]. Relative to bacterial detection (BacT/ALERT 2-bottle system, 48-hour quarantine), which was overall $66 \%$ effective, the Mirasol system was superior in reducing the number of bacterial contaminations post processing (table 3 ).

Residual leukocytes in blood products can mediate a series of adverse immunological effects in the recipient. Leukoreduction reduces, but does not entirely remove donor leukocytes from blood products. Residual leukocytes passed from donor to recipient have the capacity to induce complications in the recipient, and inactivation of donor leukocytes is essential in preventing transfusion-associated graft-versus-host disease (TA-GvHD) [35]. Gamma irradiation (25-30 Gy) is currently the accepted standard of care for transfusions in immunocompromised patients or patient populations that are particularly susceptible to TA-GvHD. Mirasol treatment is as effective as gamma irradiation in inactivating leukocytes [36, 37], providing an alternative to gamma irradiation. Additional 
Table 4. Leukocyte inactivation after Mirasol PRT treatment [35, 37-39, 79]

\begin{tabular}{ll}
\hline & Extent of inactivation after PRT treatment \\
\hline $\begin{array}{l}\text { In vitro } \\
\text { Limiting dilution assay (LDA) } \\
\text { Cytokine synthesis }\end{array}$ & $>6 \log _{10}$ reduction of viable T cells \\
& $\begin{array}{l}\text { elimination of IL-8 and IL-1 } \beta \text { release during storage } \\
\text { endimination IL-2, IL-4, IL-5, IL-10, TNF- } \alpha \text {, IFN- } \gamma,\end{array}$ \\
& $\begin{array}{l}\text { IL- } 8, \text { IL-1 } \beta, \text { IL-6, IL-12 p70 synthesis upon activation } \\
\text { prevented in mixed lymphocyte cultures }\end{array}$ \\
Antigen presentation & \\
\hline In vivo & prevention of TA-GvHD \\
Murine transfusion model & prevention of allo-antibody formation \\
Rat allo-immunization model &
\end{tabular}

benefits of Mirasol treatment, beyond the prevention of TAGvHD, may come from the prevention of alloimmunization and cytokine production (table 4). Data currently available indicate that Mirasol-treated leukocytes are incapable of stimulating or binding to allogeneic cells [38], that they prevent alloimmunization in an animal model [39] and that they mediate less of a decrease in platelet count increments with increasing numbers of transfusions in the clinical setting [37]. Elimination of cytokine production is beneficial because cytokine accumulation in stored platelet products has been associated with the occurrence of febrile nonhemolytic transfusion reactions. The cytokines such as IL-8, IL-6 and TNF- $\alpha$ are also known as endogenous pyrogens. After Mirasol treatment significantly lower amounts of TNF- $\alpha$, IL- 6 and IL- 8 are detected in supernatants of treated leukocytes than in untreated or gamma-irradiated control cells [36, 79].

\section{Mirasol PRT System for Platelets}

It is critical that Mirasol-treated platelets remain viable and hemostatically effective. A series of in vitro studies were performed to assess platelet quality after Mirasol treatment, and a correlation between in vitro parameters and in vivo performance was established [40]. In these studies $\mathrm{pH}$ and lactate production rate were found to be most strongly correlated with the in vivo recovery and survival of Mirasol-treated platelets [40]. Glucose consumption rate and swirl also showed some correlation with these in vivo parameters, though to a lesser extent. P-selectin, $\mathrm{pO}_{2}$ and $\mathrm{pCO}_{2}$ expression in Mirasol-treated platelets, however, were poorly correlated with in vivo platelet recovery and survival. These relationships formed the basis for the platelet quality evaluations of the Mirasol PRT system during the development and initial field evaluations.

Changes in cell quality parameters do occur; in particular metabolism is up-regulated in treated platelets, and treatment induces some degree of platelet activation. However, shearinduced adhesion is maintained in Mirasol-treated platelets [41-43], and mitochondrial function is preserved [44, 45]. De- spite the fact that mitochondrial DNA is fragmented by the treatment [11], the wavelength of UV light used in the process is distinct from the one where cytochrome C, FMN and FAD absorb (370-450 nm) [46], resulting in intact electron transfer processes within mitochondrial membranes. Low oxygen levels in the treated products are a simple measurement and indication of functional mitochondria, since oxygen is consumed and ATP produced during mitochondrial respiration [44, 45]. Additional evidence that mitochondria are intact after Mirasol treatment comes from the use of PAS, in which acetate is used as a substitute for glucose. Mitochondria of Mirasoltreated platelets are able to convert acetate and make ATP as a result [47]. Again, in order for this to occur, the mitochondrial respiratory path must be intact. This finding is important because mitochondrial respiration plays a critical role in the activation and effectiveness of platelets during clot formation at sites of vascular injury [48]. In the absence of this functionality, reduced or limited effectiveness of platelets in stopping or preventing bleeding may be an undesirable consequence [49].

The quality of Mirasol-treated platelets obtained from various apheresis platforms or from whole blood have been extensively evaluated. The Mirasol system's treatment capability allows treatment of platelets collected in plasma or PAS, with SSP+ (MacoPharma, Langen, Germany) being the recommended PAS for longer storage. The ability to treat hyperconcentrated plasma reduced platelet units that require the addition of PAS after treatment enables the user to treat double and triple products and split them for storage. Treated units can be stored for up to 5 days under standard blood banking conditions. Table 5 provides an overview of the parameters evaluated at external sites and appropriate references.

\section{Clinical Experience}

In a randomized controlled trial (MIRACLE trial) [50] the efficacy and safety of PRT-treated platelets was evaluated. A total of 678 platelet transfusions were given to 110 patients during the study (56 in the Mirasol and 54 in the reference group). The average 1-hour corrected count increment (CCI) 
Table 5. In vitro platelet quality assessment

\begin{tabular}{|c|c|c|}
\hline Parameters & Measures & References \\
\hline Metabolic parameters & $\begin{array}{l}\mathrm{pH}\left(22^{\circ} \mathrm{C}\right) \\
\text { lactate production rate } \\
\text { glucose consumption rate } \\
\mathrm{pO}_{2} \\
\mathrm{pCO}_{2}\end{array}$ & {$[11,45,80-85]$} \\
\hline Activation markers & P-selectin expression & \\
\hline Morphology and membrane integrity parameters & $\begin{array}{l}\text { swirl } \\
\text { hypotonic shock response (HSR) } \\
\text { annexin V release (indicates loss of membrane integrity and cellular injury) }\end{array}$ & \\
\hline Mitochondrial structure and function parameters & $\begin{array}{l}\text { JC- } 1 \text { signal (measures mitochondrial transmembrane potential) } \\
\text { MTT reduction assay (measures mitochondrial enzymatic activity) } \\
\text { ATP concentration in platelets }\end{array}$ & {$[44,86]$} \\
\hline
\end{tabular}

Table 6. Clinical evaluations $[50,88-91]$

\begin{tabular}{lclll}
\hline Site & Number of transfusions & 24-hour CCI & Adverse events & Neoantigen formation \\
\hline MIRACLE trial - reference group & 160 & 9,886 & 3 (severe*) & ND \\
MIRACLE trial - Mirasol group & 175 & 6,676 & 2 (severe*) & none \\
Serbia & 87 & 5,166 & none & none \\
Poland & 4,328 & ND & 12 (grade 1 ${ }^{*}$ ) & none \\
Spain & 44 & 6,351 & none & ND \\
Mirasol evaluation program & 368 & ND & none & ND \\
*The following categories of adverse event severity were used: Mild: Awareness of a sign or symptom that does not interfere \\
with the patients usual activity or is transient, resolves without treatment and with no sequelae. Moderate: Interferes with the \\
patient's usual activity and/or requires symptomatic treatment. Severe: Symptom(s) causing severe discomfort and significant \\
impact of the patients usual activity and requires treatment. \\
"Severity of reactions followed the classification suggested by the International Hemovigilance Network. Grade 1: The recipi- \\
ent required no more than discontinuation of transfusion and symptomatic management. No long-term morbidity. Grade 2: \\
The recipient requires in-patient hospitalization or prolongation of hospitalization due to hypotension, or hypotension led \\
directly to long-term morbidity.
\end{tabular}

in the Mirasol-treated group was 11,725 $\pm 1,140$ and in the reference group $16,939 \pm 1,149$. In order to meet the non-inferiority criterion, the absolute difference between the two arms needed to be less than 2,940, hence non-inferiority could not be claimed, while inferiority could not be established due to the fact that the variability observed in the CCI values exceeded the planned margins used in establishing the sample size. Average 24-hour CCI was $6,676 \pm 883$ for PRTtreated and 9,886 \pm 915 for untreated platelets. $71.3 \%$ of the Mirasol-treated products resulted in successful transfusion increment compared to $84.1 \%$ in the reference group (success is defined by 1 -hour CCI values $\geq 7,500$ [51]). When assessed at $24 \mathrm{~h}$ post transfusion, the proportions were $58.9 \%$ and $68.1 \%$ for Mirasol-treated and reference platelets, respectively (success is defined by 24 -hour CCI values $\geq 4,500$ [51]). These percentages are within the ranges that have been reported in other studies [49]. Importantly, no differences be-

tween the Mirasol-treated and control group were detected for mean number of days between transfusions, mean number of platelet transfusions per patient and dose of platelets transfused. Safety data did not identify any major adverse events associated with the transfusion of Mirasol-treated platelets. The frequencies of all adverse events and severe adverse events were similar between both treatment arms. Two patients in the Mirasol-treated group (1.8\%) had severe adverse events that were 'very likely' related to a transfusion (refractoriness in both cases), and 2 patients in the reference arm had events categorized as 'very likely' related (eyelid edema and anaphylactic shock) (table 6).

At the time of manuscript preparation post market surveillance on over 6,000 transfusions revealed no device-related adverse events. Published clinical data from sites evaluating and using the Mirasol system in routine is summarized in table 6. 


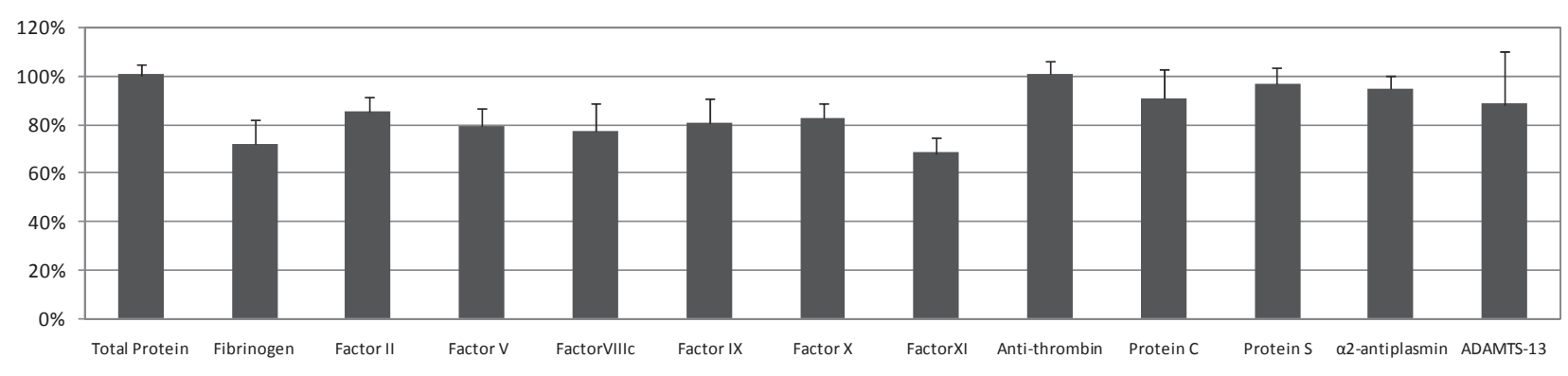

Fig. 1. Average percent plasma protein retention for coagulants from external validation [55-57].

\section{Mirasol PRT System for Plasma}

Pathogen reduction techniques were first developed for plasma, and PRT-treated plasma products have been on the market in Europe for more than a decade. FFP intended for transfusion to patients must contain adequate functional levels of coagulation factors and other therapeutically valuable proteins. Protein levels should be as close as possible to those found in fresh plasma [52]. Blood component processing can affect the quality of plasma products, particularly labile coagulation factors such as factors V and VIII. Plasma frozen within $8 \mathrm{~h}$ of collection shows the highest levels of coagulation factor retention. Plasma separated from whole blood donations and frozen below $-18{ }^{\circ} \mathrm{C}$ within $24 \mathrm{~h}$ of collection still shows good retention of coagulation activity. However, when compared with historic data on FFP frozen within $8 \mathrm{~h}$, levels of fibrinogen, factor V, factor VIII and factor XI in FFP frozen within $24 \mathrm{~h}$ have been shown to be reduced by $12 \%, 15 \%$, $23 \%$ and $7 \%$, respectively [53].

As shown in figure 1, Mirasol-treated FFP shows high overall protein retention under a broad range of blood banking conditions. Mirasol-treated FFP meets the Council of Europe $(\mathrm{CoE})$ guidelines [54], with external validation studies showing on average factor VIIIc levels of $0.8 \pm 0.2 \mathrm{IU} / \mathrm{ml}$ post treatment [55-57]. Protein content meets $\mathrm{CoE}$ guidelines even when whole blood is held overnight at room temperature and plasma is separated up to $18 \mathrm{~h}$ or frozen up to $24 \mathrm{~h}$ after collection. Additionally, anticoagulant factors such as protein $\mathrm{C}$ and protein $\mathrm{S}$ are well preserved after treatment with a $96 \%$ retention reported post treatment for both proteins [56]. Extended storage at $-30{ }^{\circ} \mathrm{C}$ for up to 2 years does not significantly decrease protein quality [58]. The option to Mirasoltreat previously frozen plasma has also been validated and enables sites to treat products already in inventory [59].

Many countries use cryoprecipitate prepared from plasma to treat hypofibrinogenemia, von Willebrand disease, hemophilia and in massive transfusion situations in combination with other blood components. Cryoprecipitate contains the major portion of factor VIII, von Willebrand factor, fibrino- gen, factor XIII, and fibronectin of freshly thawed plasma. Cryoprecipitate made from Mirasol-treated FFP exceeds the $\mathrm{CoE}$ requirements containing $95 \pm 21 \mathrm{IU} /$ unit factor VIII and $272 \pm 50 \mathrm{mg} / \mathrm{unit}$ fibrinogen (manuscript in preparation).

\section{Clinical Experience}

Observational clinical studies in three European countries are ongoing to assess product performance in routine use. Several blood banks in Poland implemented Mirasol-treated plasma and platelets, and more than 10,000 plasma units have been treated to date with the Mirasol process. No device-related adverse events have been reported. The Blood Transfusion Institute in Nis, Serbia, evaluated the clinical performance of treated products in patients with hypoprothrombinemia by international normalized ratio (INR). INR is a measurement to standardize results for prothrombin time (normal range 0.81.2) since results vary depending on what type of analytical system is used. A mean decrease in INR of 0.49 (range 0.33 0.80) after transfusion of Mirasol-treated plasma was observed, an acceptable decrease in coagulation time [60].

\section{Mirasol System for Whole Blood}

The Mirasol system is being further developed for the treatment of whole blood, providing a single pathogen reduction and leukocyte inactivation step, followed by the use of the product as whole blood or separation into components. The treatment of RBCs or whole blood has been more challenging due to the absorption of light by hemoglobin. Although the peak absorption of hemoglobin $(400-450 \mathrm{~nm})$ is outside the spectral region of the Mirasol lamp output, the UV light energy dose delivered to units of whole blood is normalized for $\mathrm{RBC}$ volume $\left(\mathrm{J} / \mathrm{ml}_{\mathrm{RBC}}\right)$.

As part of the development of the Mirasol System for Whole Blood in vitro parameters that may predict 24-hour survival of RBCs in vivo were established in a clinical evaluation (Cancelas et al., manuscript submitted for publication). In this study component quality and leukocyte inactivation 
was assessed after the addition of $35 \mathrm{ml}$ of RB solution (500 $\mu \mathrm{mol} / \mathrm{l}$ ) to whole blood units and exposure to 22,33 and $44 \mathrm{~J} /$ $\mathrm{ml}_{\mathrm{RBC}} \mathrm{UV}$ light. Mirasol-treated packed RBCs were stored for 42 days prior to infusion of small aliquots of radiolabeled RBCs into healthy volunteers. The study showed that key RBC cell quality parameters, such as hemolysis and ATP concentration, may be predictive of their 24-hour recovery and T50 survival. These variables were used to assess modifications to the system, including storage duration, storage temperature and appropriate energy dose for treatment. Mirasoltreated platelet concentrates were stored for 5 days, and Mirasol-treated FFP was stored frozen for 28 days. The mean $\mathrm{pH}$ of stored platelet units on day 5 met $\mathrm{AABB}$ requirements, and no platelet loss during storage was observed. Overall protein retention after treatment was not significantly affected and levels of fibrinogen, factors V, VIIIc and XI were on average higher than reported for PRT-treated plasma (fig. 1).

Treatment with the Mirasol System for Whole Blood in the current configuration exposes units to $80 \mathrm{~J} / \mathrm{ml}_{\mathrm{RBC}} \mathrm{UV}$ light; this treatment energy was chosen to balance blood component quality, pathogen reduction and storage length. After treatment whole blood can be separated into components that are stored according to standard procedures. Hemolysis in Mirasol-treated RBCs increased during storage and was on average below $1 \%$ on day 35 of storage. Potassium increased and sodium levels decreased in treated units compared to untreated controls [61]. Osmotic fragility curves were similar for Mirasol-treated and untreated units throughout 42 days of storage [62]. Plasma factor activities in Mirasol-treated FFP were lower than in untreated control units, but comparable to levels observed in Mirasol-treated plasma (fig. 1). Platelet swirl and $\mathrm{pH}$ was not affected by the treatment during 5 days of storage, whereas glucose consumption and lactate production were enhanced as previously described [63].

In addition, the storage of Mirasol-treated whole blood is being evaluated. A whole blood product stored for short periods of time (24-48 h) at room temperature would be useful for massively transfused patients in military or trauma settings. $\mathrm{RBC}$ and platelet quality was assessed during storage of whole blood for 7 days. RBC hemolysis remained at background levels for all units tested throughout storage [64]. Platelet function was evaluated via ImpactR and thromboelastography (TEG) - methods to assess the adhesion and aggregation potential of platelets. No significant differences were detected between Mirasol-treated and untreated control platelets when whole blood units were stored for 7 days [65].

The effectiveness of the Mirasol System for Whole Blood was evaluated with tests of pathogen reduction (virus, bacteria and parasite reduction) and leukocyte inactivation. Virus reduction tests used non-enveloped (blue tongue virus, HAV and canine parvovirus) and enveloped (vesicular stomatitis virus, infectious bovine rhinotracheitis virus) viruses. All viruses were susceptible to inactivation, ranging from $1.2 \mathrm{log} / \mathrm{ml}$ reduction levels for HAV to $4.5 \mathrm{log} / \mathrm{ml}$ for vesicular stomatitis virus [62]. The treatment was $100 \%$ effective against bacteria commonly found in RBC units (S. liquefaciens and Y. enterocolitica). Contamination of whole blood units with different strains of S. epidermidis, found in $20 \%$ of contaminated platelet units as reported in hemovigilance studies [33], yielded $83-100 \%$ effectiveness depending on the bacterial strain. Effectiveness against S. epidermidis (ATCC \# 12228) was 83\%, whereas the ability of the culture system to detect this particular strain (BacT/ALERT) has been shown to be 27\% [34]. A study in whole blood evaluating the effectiveness of the system against infectious T. cruzi, the causative agent of causes Chagas disease, showed reduction to the limit of detection of the assay at clinically relevant parasite concentrations [66]. Leukocytes are inactivated to the limit of detection of the assays at energies of 33 and $44 \mathrm{~J} / \mathrm{ml}_{\mathrm{RBC}}$, and engraftment of human T cells in a murine GvHD model is prevented [34].

\section{Conclusion}

Blood transfusions are life-saving but unfortunately can also serve as a potential vector for the spread of disease. The Mirasol PRT System is capable of inactivating significant levels of pathogens and leukocytes and is thus expected to reduce the risk of disease transmission and adverse events while maintaining acceptable quality of the treated blood products. Pathogen reduction of blood components represents a means to address concerns about disease transmission via blood transfusions, but sufficient benefit and cost-effectiveness to warrant implementation of the technology must be established. Custer et al. [67] developed a new health economics model to assess the costeffectiveness of the Mirasol system in mitigating the risk of transfusion-associated infectious and some non-infectious threats. In this publication they used quality-adjusted life year (QALY) as a measure to assess the monetary value of a medical intervention. The value is based on the number of years of life that would be added by the intervention. The incremental cost-effectiveness of Mirasol-treated platelets and plasma is USD 1,423,000/QALY compared to current screens and interventions. The incremental cost-effectiveness of the Mirasol System for Whole Blood compared to current screens and interventions is USD 1,276,000/QALY. If Mirasol treatment were to be adopted, it could be even more cost-effective than reported here since bacterial culture for platelets and gamma irradiation for leukocyte inactivation could potentially be eliminated. This value compares to the cost-effectiveness of HIV and HCV NAT testing, a technology that has been broadly adopted, exceeding USD 1.5 million/QALY in the USA [68, 69].

The efficacy of pathogen-inactivated or pathogen-reduced platelet products has been established in clinical trials by tracking post-transfusion CCI. However, whether 1-hour and 24-hour CCI measurements have the sensitivity and specificity to be clinically meaningful is the subject of debate. The use of bleeding as a primary endpoint has more clinical rele- 
Table 7. Ongoing clinical trials

\begin{tabular}{llll}
\hline & Trial size & Primary endpoint & Secondary endpoint \\
\hline $\begin{array}{l}\text { Italian Platelet Technology } \\
\text { Assessment Study (IPTAS), Italy }\end{array}$ & 840 & Number of patients with $\geq$ grade 2 bleeding & $\begin{array}{l}\text { CCI } \\
\text { platelet and RBC transfusions } \\
\text { transfusion interval } \\
\text { allo-antibody formation from Luminex assay }\end{array}$ \\
\hline $\begin{array}{l}\text { Pathogen Reduction - Extended } \\
\text { Storage Study (PRESS), Denmark }\end{array}$ & 40 & TEG measurements and correlation with CCI & $\begin{array}{l}\text { adverse events } \\
\text { bleeding }\end{array}$ \\
\hline $\begin{array}{l}\text { Pathogen Reduction Evaluation and } \\
\text { Predictive Analytical Rating Score } \\
\text { (PREPARES), the Netherlands }\end{array}$ & 618 & number of patients with $\geq$ grade 2 bleeding & $\begin{array}{l}\text { CCI } \\
\text { platelet and RBC transfusions } \\
\text { transfusion interval } \\
\text { allo-antibody formation from Luminex assay }\end{array}$ \\
\hline
\end{tabular}

vance although it is difficult to measure in a consistent manner [70]. Evaluating platelet function in patients before and after transfusion may be an approach to establish clinical performance of a treated platelet product. An ongoing clinical trial is investigating whether TEG can be a useful tool to predict transfusion outcomes by comparing Mirasol-treated and control platelets (table 7).

The clinical benefits of a Mirasol-treated platelet product may include benefits related to leukocyte inactivation. The inactivation of leukocytes prevents TA-GVHD, without the use of gamma irradiation, and may also help prevent platelet refractoriness. Prevention of immune-mediated refractoriness may significantly improve the care of patients on chronic platelet transfusion support. Ongoing clinical trials (table 7) will assess the effectiveness of the Mirasol PRT System in preventing alloimmunization, by assessing alloantibody formation in multiple transfused patients.

In contrast to PRT-treated platelet products, treated plasma has been on the market in Europe for a number of years. Review of the literature demonstrates that in vitro protein quality of treated plasma products (solvent/detergent, methylene blue, Intercept and Mirasol) is comparable and that treated plasma performs well clinically $[71,72]$.

The pathogen reduction process for whole blood has been shown to be effective in terms of pathogen reduction and leukocyte inactivation, and the quality of all three components separated from Mirasol-treated whole blood is adequately preserved. Mirasol-treated whole blood stored at room temperature retains platelet, plasma and $\mathrm{RBC}$ function that are critical to the support of massively transfused casualties. Clinical studies are being designed to establish the in vivo performance of this product.

No PRT-treated blood products are presently approved in the USA. Harvey Alter stated in a recent article that 'pathogen reduction calls for a new paradigm in transfusion safety, namely, the transition from a reactive to a proactive and preemptive strategy for the prevention of transfusion-transmitted diseases' [73]. With this in mind, when evaluating a pathogen reduction technology the traditional 6-log reduction, established by developers of sanitary solutions and pathogen reduction methods of plasma [31], must be reconsidered since it may far exceed the practical need given current tests for known viral pathogens. As these systems move into increased routine use, the balance between pathogen reduction levels and component quality must be recognized as well as the fact that there is currently no system available that affords $100 \%$ efficacy in detecting pathogens in blood products.

\section{Disclosure Statement}

Both authors are employees of CaridianBCT Biotechnologies.

\section{References}

1 Klein HG: Will blood transfusion ever be safe enough? JAMA 2000;284:238-240.

2 Moor AC, Dubbelman TM, VanSteveninck J, Brand A: Transfusion-transmitted diseases: risks, prevention and perspectives. Eur J Haematol 1999;62:1-18.

3 Goodrich RP, Platz MS: The design and development of selective, photoactivated drugs for sterilization of blood products; Drugs Future 1997;22: 159-171.

4 Kasai H, Yamaizumi Z, Yamamoto F, Bessho T, Nishimura S, Berger M, Cadet J: Photosensitized formation of 8-hydroxyguanine (7,8-dihydro-8oxoguanine) in DNA by riboflavin. Nucleic Acids Symp Ser 1992;181-182.
Korycka-Dahl M, Richardson T: Photodegradation of DNA with fluorescent light in the presence of riboflavin, and photoprotection by flavin tripletstate quenchers. Biochim Biophys Acta 1980;610: 229-234

6 Kuratomi K, Kobayashi Y: Studies on the interactions between DNA and flavins. Biochim Biophys Acta 1977;476:207-217.

7 Peak JG, Peak MJ, MacCoss M: DNA breakage caused by 334-nm ultraviolet light is enhanced by naturally occurring nucleic acid components and nucleotide coenzymes. Photochem Photobiol 1984; 39:713-716.
8 Speck WT, Rosenkranz HS: Phototherapy for neonatal hyperbilirubinemia - a potential environmental health hazard to newborn infants: a review. Environ Mutagen 1979;1:321-336.

-9 Kumar V, Lockerbie O, Keil SD, Ruane PH, Platz MS, Martin CB, Ravanat JL, Cadet J, Goodrich RP: Riboflavin and UV-light based pathogen reduction: extent and consequence of DNA damage at the molecular level. Photochem Photobiol 2004; 80:15-21. 
10 Goodrich RP, Edrich RA, Goodrich L, Scott C, Manica K, Hlavinka D, Hovenga N, Hansen E, Gampp D, Keil SD, Gilmour DI, Li J, Martin CB, Platz MS: The antiviral and antibacterial properties of riboflavin and light: applications to blood safety and transfusion medicine; in Silva E, Edwards AM, (eds): Flavins: Photochemistry and Photobiology. Comprehensive Series in Photochemical and Photobiological Sciences. Cambridge, The Royal Society of Chemistry, 2006, pp 83-113.

11 Janetzko K, Hinz K, Marschner S, Klüter H, Bugert P: Monitoring of the Mirasol Pathogen Reduction Procedure for Platelet Concentrates by PCR and bioanalyzer; Transfus Med Hemother 2007;34(suppl 1):S60.

12 Martin CB, Wilfong E, Ruane P, Goodrich R, Platz $\mathrm{M}$ : An action spectrum of the riboflavin-photosensitized inactivation of lambda phage. Photochem Photobiol 2005;81:474-480.

13 Hayashi M, Kishi M, Sofuni T, Ishidate M Jr: Micronucleus tests in mice on 39 food additives and eight miscellaneous chemicals. Food Chem Toxicol 1988;26:487-500.

14 Munoz N, Hayashi M, Bang LJ, Wahrendorf J, Crespi M, Bosch FX: Effect of riboflavin, retinol, and zinc on micronuclei of buccal mucosa and of esophagus: a randomized double-blind intervention study in China. J Natl Cancer Inst 1987;79:687-691.

15 Studer A, Zbinden G, Uehlinger E: Die Pathologie der Avitaminosen and Hypervitaminosen; in Buchner F, Letterer E, Roulet F (Hrsg): Handbuch der Allgemeinen Pathologie. Berlin, Springer, 1962, pp 734-987.

16 Unna K, Greslin JG: Studies on the toxicity and pharmacology of riboflavin. J Pharmacol 1942 76:75-80.

17 Bates CJ: Human requirements for riboflavin. Am J Clin Nutr 1987:46:122-123.

-18 Kostenbauder HB, DeLuca PP, Kowarski CR: Photobinding and photoreactivity of riboflavin in the presence of macromolecules. J Pharm Sci 1965;54:1243-1251.

19 Sisson TR: Photodegradation of riboflavin in neonates. Federation Proc 1987;46:1883-1885.

20 Yurdakok M, Erdem G, Tekinalp G: Riboflavin in the treatment of neonatal hyperbilirubinemia Turkish J Pediatr 1988;30:159-161.

-21 Olsen JH, Hertz H, Kjaer SK, Bautz A, Mellemkjaer L, Boice JD Jr: Childhood leukemia following phototherapy for neonatal hyperbilirubinemia (Denmark). Cancer Causes Control 1996;7:411414.

-22 Hardwick CC, Herivel TR, Hernandez SC, Ruane $\mathrm{PH}$, Goodrich RP: Separation, identification and quantification of riboflavin and its photoproducts in blood products using high-performance liquid chromatography with fluorescence detection: a method to support pathogen reduction technology. Photochem Photobiol 2004;80:609-615.

23 Expert Group on Vitamins and Minerals: Revised review of riboflavin:. 2002, pp 1-48. www.food.gov. uk/multimedia/pdfs/reviewriboflavin.

24 BIBRA Working Group: Riboflavin and its derivatives: toxicity profile. Epscm, Surrey, BIBRA, 1990, pp 1-7.

25 Reddy H, Buytaert-Hoefen K, Hovenga N, Gampp D, White J, Goodrich R: Acute toxicity of Mirasol PRT-treated FFP in plasma exchange in dogs. Transfusion 2007;47(suppl):P75A.

26 Reddy HL, Dayan AD, Cavagnaro J, Gad S, Li J, Goodrich RP: Toxicity testing of a novel riboflavin-based technology for pathogen reduction and white blood cell inactivation. Transfus Med Rev 2008;22:133-153.

Overview of the Mirasol ${ }^{\circledR}$ Pathogen Reduction Technology System
27 Ambruso DR, Thurman G, Marschner S, Goodrich RP: Lack of antibody formation to platelet neoantigens after transfusion of riboflavin and ultraviolet light-treated platelet concentrates. Transfusion 2009;49:2631-2636.

28 Goodrich R, Murthy K, Doane S, Fitzpatrick C, Morrow L, Arndt P, Reddy H, Buytaert-Hoefen $\mathrm{K}$, Garraty G: Evaluation of potential immune response and in vivo survival of riboflavin-ultraviolet light-treated red blood cells in baboons. Transfusion 2009; 49:64-74.

29 Silliman CC, Khan SY, Ball JB, Kelher MR, Marschner S: Mirasol Pathogen Reduction Technology treatment does not affect acute lung injury in a two-event in vivo model caused by stored blood components. Vox Sang 2010;98:525-530.

30 Levy R, Herzberg GR, Andrews WL, Sutradhar B, Friel JK: Thiamine, riboflavin, folate, and vitamin B12 status of low birth weight infants receiving parenteral and enteral nutrition. JPEN J Parenter Enteral Nutr 1992;16:241-247.

31 Goodrich RP, Custer B, Keil S, Busch M: Defining adequate pathogen reduction performance for transfused blood components. Transfusion 2010; 50:1827-1837.

32 McDonald CP, Roy A, Mahajan P, Smith R, Charlett A, Barbara JA: Relative values of the interventions of diversion and improved donor-arm disinfection to reduce the bacterial risk from blood transfusion. Vox Sang 2004;86:178-182.

33 Brecher ME, Hay SN: Bacterial contamination of blood components. Clin Microbiol Rev 2005;18: 195-204.

34 Goodrich RP, Gilmour D, Hovenga N, Keil SD: A laboratory comparison of pathogen reduction technology treatment and culture of platelet products for addressing bacterial contamination concerns. Transfusion 2009;49:1205-1216.

35 Fast LD, DiLeone G, Cardarelli G, Li J, Goodrich R: Mirasol PRT treatment of donor white blood cells prevents the development of xenogeneic graft-versus-host disease in Rag2-/-gamma c-/- double knockout mice. Transfusion 2006;46:1553-1560.

36 Fast LD, DiLeone G, Marschner S: Inactivation of human white blood cells in platelet products after pathogen reduction technology treatment in comparison to gamma irradiation. Transfusion 2010; doi: 10.1111/j.1537-2995.2010.02984.x.

37 Marschner S, Fast LD, Baldwin WM III, Slichter SJ, Goodrich RP: White blood cell inactivation after treatment with riboflavin and ultraviolet light. Transfusion 2010;50:2489-2498.

38 Jackman R, Heitman J, Marschner S, Goodrich R, Norris PJ: Understanding loss of donor white blood cell immunogenicity following pathogen reduction: mechanisms of action in UV illumination and riboflavin treatment; Transfusion 2009;49:2686-2699.

39 Asano H, Lee CY, Fox-Talbot K, Koh CM, Erdinc MM, Marschner S, Keil S, Goodrich RP, Baldwin WM: Treatment with riboflavin and ultraviolet light prevents alloimmunization to platelet transfusions and cardiac transplants. Transplantation 2007;84:1174-1182.

40 Goodrich RP, Li J, Pieters H, Crookes R, Roodt J, Heyns A: Correlation of in vitro platelet quality measurements with in vivo platelet viability in human subjects. Vox Sang 2006;90:279-285.

41 Marschner S, Hovenga N, Goodrich RP: Coagulation potential of Mirasol Pathogen Reduction technology treated platelets. Vox Sang 2010;99:247.

42 Perez-Pujol S, Tonda R, Lozano M, Fuste B, Lopez-Vilchez I, Galan AM, Li J, Goodrich R, Escolar G: Effects of a new pathogen-reduction technology (Mirasol PRT) on functional aspects of platelet concentrates. Transfusion 2005;45:911-919.
Picker SM, Schneider V, Gathof BS: Platelet function assessed by shear-induced deposition of split triple-dose apheresis concentrates treated with pathogen reduction technologies. Transfusion 2009; 49:1224-1232.

44 Li J, Lockerbie O, de KD, Rice J, McLean R, Goodrich RP: Evaluation of platelet mitochondria integrity after treatment with Mirasol pathogen reduction technology. Transfusion 2005;45:920-926.

45 Picker SM, Schneider V, Oustianskaia L, Gathof BS: Cell viability during platelet storage in correlation to cellular metabolism after different pathogen reduction technologies. Transfusion 2009;49:23112318.

46 Hockberger PE, Skimina TA, Centonze VE, Lavin C, Chu S, Dadras S, Reddy JK, White JG: Activation of flavin-containing oxidases underlies lightinduced production of $\mathrm{H}_{2} \mathrm{O}_{2}$ in mammalian cells. Proc Natl Acad Sci U S A 1999;96:6255-6260.

47 Marschner S, Hovenga N, Gathof BS, Picker SM, de Korte D, Goodrich R: Acetate consumption in platelets treated with different pathogen reduction technologies. Vox Sang 2010;99:247.

48 Akkerman J-W, Verhoeven AJ: Energy Metabolism and Function; in Holmsen H (ed): Platelet Responses and Metabolism. Vol. 3: Response-Metabolism Relationships. Boca Raton, CRC Press, 1987, pp 69-99.

49 Kerkhoffs JL, van Putten WL, Novotny VM, Te Boekhorst PA, Schipperus MR, Zwaginga JJ, van Pampus LC, de Greef GE, Luten M, Huijgens PC, Brand A, van Rhenen DJ: Clinical effectiveness of leucoreduced, pooled donor platelet concentrates, stored in plasma or additive solution with and without pathogen reduction. Br J Haematol 2010;150:209-217.

50 Cazenave JP, Folléa G, Bardiaux L, Boiron JM Lafeuillade B, Debost M, Lioure B, Harousseau JL, Tabrizi R, Cahn JY, Michallet M, Ambruso D, Schots R, Tissot JD, Sensebé L, Kondo T, McCullough J, Rebulla P, Escolar G, Mintz P, Heddle NM, Goodrich RP, Bruhwyler J, Le C, Cook RJ, Stouch B; for members of the The Mirasol Clinical Evaluation Study Group: A randomized controlled clinical trial evaluating the performance and safety of platelets treated with MIRASOL pathogen reduction technology: Transfusion 2010;50:23622375.

51 British Committee for Standards in Haematology, Blood Transfusion Task Force: Guidelines for the use of platelet transfusions: $\mathrm{Br} \mathrm{J}$ Haematol 2003;122:10-23.

52 Solheim BG, Seghatchian J: Update on pathogen reduction technology for therapeutic plasma: an overview. Transfus Apher Sci 2006;35:83-90.

53 Cardigan R, Lawrie AS, Mackie IJ, Williamson LM: The quality of fresh-frozen plasma produced from whole blood stored at 4 degrees $\mathrm{C}$ overnight. Transfusion 2005;45:1342-1348.

54 Keitel S (ed): Guide to the Preparation, Use and Quality Assurance of Blood Components Strasbourg, Council of Europe, 2009, pp 256-258.

55 Hornsey VS, Drummond O, Morrison A, McMillan L, MacGregor IR, Prowse CV: Pathogen reduction of fresh plasma using riboflavin and ultraviolet light: effects on plasma coagulation proteins. Transfusion 2009;49:2167-2172.

56 Larrea L, Calabuig M, Roldan V, Rivera J, Tsai HM, Vicente V, Roig R: The influence of riboflavin photochemistry on plasma coagulation factors. Transfus Apher Sci 2009;41:199-204.

57 Smith J, Rock G: Protein quality in Mirasol pathogen reduction technology-treated, apheresis-derived fresh-frozen plasma. Transfusion 2010;50:926-931. 
58 Bihm D, Ettinger A, Buytaert-Hoefen K, Hendrix B, Maldonado-Codina G, Rock G, Giclas P, Goodrich RP: Characterization of plasma protein activity in riboflavinand UV light-treated fresh frozen plasma during 2 years of storage at $-30^{\circ} \mathrm{C}$. Vox Sang 2010;98:108-115.

59 Ettinger A, Miklauz MM, Hendrix B, Bihm D, Maldonado-Codina G, Goodrich RP: Protein stability of previously frozen plasma, riboflavin and UV light-treated, refrozen and stored for up to 2 years at $-30{ }^{\circ} \mathrm{C}$. Transfus Apher Sci 2010; (in press).

60 Antic A, Stanijkovic Z: Clinical performance of buffy coat platelets treated with riboflavin and UV light. Transfusion 2010;50(suppl):p66A.

61 Cancelas J, Rugg N, Worsham DN, Pratt GP, Dunn SK, Reddy H, Fletcher D, Goodrich RP: Quality assessment of stored RBC after treatment of whole blood with the Mirasol System. Transfusion 2010;50(suppl):p71A.

62 Goodrich RP, Doane S, Reddy HL: Design and development of a method for the reduction of infectious pathogen load and inactivation of white blood cells in whole blood products. Biologicals 2010;38:20-30.

63 Li J, Goodrich L, Hansen E, Edrich R, Gampp D, Goodrich RP: Platelet glycolytic flux increases stimulated by ultraviolet-induced stress is not the direct cause of platelet morphology and activation changes: possible implications for the role of glucose in platelet storage. Transfusion 2005;45:1750 1758.

64 Reddy H, Marschner S, Doane S, Spotts C, Goodrich RP: Room temperature storage of whole blood treated with the Mirasol System. Vox Sang 2010;99:p243.

65 Reddy H, Doane S, Spotts C, Goodrich RP: In vitro assessments of platelet function in whole blood treated with the Mirasol System and stored at room temperature. Vox Sang 2010;99:p243.

66 Tonnetti L, Thorp AM, Reddy H, Goodrich RP Leiby DA: Evaluation of the reduction of T cruzi with the Mirasol System for Whole Blood. Transfusion 2010;50(suppl):p209A.

67 Custer B, Agapova M, Martinez RH: The costeffectiveness of pathogen reduction technology as assessed using a multiple risk reduction model. Transfusion 2010;50:2461-2473.

68 Jackson BR, Busch MP, Stramer SL, AuBuchon JP: The cost-effectiveness of NAT for HIV, HCV, and HBV in whole-blood donations. Transfusion 2003;43:721-729.

69 Marshall DA, Kleinman SH, Wong JB, AuBuchon JP, Grima DT, Kulin NA, Weinstein MC: Costeffectiveness of nucleic acid test screening of volunteer blood donations for hepatitis B, hepatitis C and human immunodeficiency virus in the United States. Vox Sang 2004;86:28-40.
70 Heddle NM: Optimal timing and dosing of platelet transfusions. ISBT Science Series 2010;5:88-94.

71 Prowse C: Properties of pathogen-inactivated plasma components. Transfus Med Rev 2009;23:124133.

72 Rock G: A comparison of methods of pathogen inactivation of FFP. Vox Sang 2010; DOI: 10.1111/ j.1423-0410.2010.01374.x.

73 Alter HJ: Pathogen reduction: a precautionary principle paradigm. Transfus Med Rev 2008;22:97102.

74 Cardo LJ, Rentas FJ, Ketchum L, Salata J, Harman R, Melvin W, Weina PJ, Mendez J, Reddy H, Goodrich R: Pathogen inactivation of Leishmania donovani infantum in plasma and platelet concentrates using riboflavin and ultraviolet light. Vox Sang 2006;90:85-91.

75 Cardo LJ, Salata J, Mendez J, Reddy H, Goodrich R: Pathogen inactivation of Trypanosoma cruzi in plasma and platelet concentrates using riboflavin and ultraviolet light. Transfus Apher Sci 2007; 37:131-137.

76 Rentas F, Harman R, Gomez C, Salata J, Childs J, Silva T, Lippert L, Montgomery J, Richards A, Chan C, Jiang J, Reddy H, Li J, Goodrich R: Inactivation of Orientia tsutsugamushi in red blood cells, plasma, and platelets with riboflavin and light, as demonstrated in an animal model. Transfusion 2007:47:240-247.

77 Sullivan J, Bounngaseng A, Reddy H, Keil S, Goodrich RP: Inactivation of Plasmodium falciparum in plasma and platelet concentrates with riboflavin and UV light. Vox Sang 2008;95:p278.

78 Tonnetti L, Proctor MC, Reddy HL, Goodrich RP, Leiby DA: Evaluation of the Mirasol pathogen [corrected] reduction technology system against Babesia microti in apheresis platelets and plasma. Transfusion 2010;50:1019-1027.

79 Fast LD, DiLeone G, Li J, Goodrich R: Functional inactivation of white blood cells by Mirasol treatment. Transfusion 2006:46:642-648.

80 Li J, de Korte D, Woolum MD, Ruane PH, Keil SD, Lockerbie O, McLean R, Goodrich RP: Pathogen reduction of buffy coat platelet concentrates using riboflavin and light: comparisons with pathogen-reduction technology-treated apheresis platelet products. Vox Sang 2004;87:82-90.

81 Ostrowski SR, Bochsen L, Salado-Jimena JA, Ullum H, Reynaerts I, Goodrich RP, Johansson PI: In vitro cell quality of buffy coat platelets in additive solution treated with pathogen reduction technology. Transfusion 2010;50:2210-2219.
2 Picker SM, Steisel A, Gathof BS: Effects of Mirasol PRT treatment on storage lesion development in plasma-stored apheresis-derived platelets compared to untreated and irradiated units. Transfusion 2008;48:1685-1692.

83 Picker SM, Oustianskaia L, Schneider V, Gathof BS: Functional characteristics of apheresis-derived platelets treated with ultraviolet light combined with either amotosalen-HCl (S-59) or riboflavin (vitamin B2) for pathogen-reduction. Vox Sang 2009;97:26-33.

4 Picker SM, Oustianskaia L, Schneider V, Gathof BS: Annexin V release and transmembrane mitochondrial potential during storage of apheresisderived platelets treated for pathogen reduction. Transfus Med Hemother 2010;37:7-12.

-85 Ruane PH, Edrich R, Gampp D, Keil SD, Leonard RL, Goodrich RP: Photochemical inactivation of selected viruses and bacteria in platelet concentrates using riboflavin and light. Transfusion 2004; 44:877-885.

86 Picker SM, Steisel A, Gathof BS: Cell integrity and mitochondrial function after Mirasol-PRT treatment for pathogen reduction of apheresis-derived platelets: Results of a three-arm in vitro study. Transfus Apher Sci 2009;40:79-85.

87 Galan AM, Lozano M, Molina P, Navalon F, Marschner S, Goodrich R, Escolar G: Impact of pathogen reduction technology and storage in platelet additive solutions on platelet function. Transfusion 2010; doi: 10.1111/j.1537-2995.2010. 02914.x

88 Cardoso M, Piotrowski D, Przybylska-Baluta Z, Leleno M, Uszynska A: Transfusion experience with platelet concentrates treated with the Mirasol PRT System in the regional BTS Warsaw. Transfusion 2010;50(suppl):p67A.

89 Marschner S, Villaescusa RD, Perez Vaquero MA, De Fusco G, Arroyo L, Pierelli L, Nucci S, Freitas A: The Mirasol Evaluation Program: use of Mirasol Pathogen Reduction Technologyfor platelets in routine clinical practice. Vox Sang 2009;96(suppl 1):229.

90 Stanojkovic ZA, Antic AM, Stanijkovic M: Clinical performance of buffy coat platelets treated with riboflavin and UV light. Transfusion 2010;50 (suppl):p66A

91 Yanez M, Blanco L, Gonzalez A, Moya A, De Coca G, Cuello R: Performance of buffy coat platelets in plasma treated with riboflavin and UV light: in vitro and in vivo evaluation. Transfusion 2010;50(suppl):p84A. 